\title{
Vitamin D and rheumatic diseases
}

\author{
M. Rossini, D. Gatti, O. Viapiana, C. Caimmi, L. Idolazzi, E. Fracassi, S. Adami \\ Rheumatology Unit, University of Verona, Italy
}

\begin{abstract}
SUMMARY
Vitamin D has some well-known effects on calcium, phosphate and bone metabolism, but it has recently shown to have many other effects, which may potentially be relevant to patients with extra-skeletal rheumatic diseases. Such effects may be justified by:

1) the presence of the vitamin D receptors also on extra-osseous cells, such as cartilage cells, sinoviocytes, muscle cells;

2) the proven role of vitamin D in the control of the transcription of genes involved in rheumatic diseases;

3) the evidence that vitamin D has multiple endocrine effects not only on calcium homeostasis;

4) the activation of vitamin D not only in the kidneys, but also in monocyte-macrophage and lymphocytic cell lines and in some epithelial cells with additional intracrine and paracrine effects.

Vitamin D deficiency has been reported in numerous metabolic, degenerative, inflammatory and autoimmune rheumatic diseases. In some cases this association was also related to the risk of developing a rheumatic disease or the degree of disease activity. However there is no conclusive evidence of the efficacy of a preventive or therapeutic strategy based on vitamin D supplementation in extra-skeletal rheumatic diseases.

This review aims to provide an overview of the latest evidence concerning the relationship between vitamin D and the most relevant rheumatic diseases.
\end{abstract}

Key words: Vitamin D, Rheumatic diseases.

Reumatismo, 2014; 66 (2): 153-170

\section{INTRODUCTION}

$\mathrm{B}$ esides the well-known effects of vitamin D on the skeleton and on phosphorus and calcium metabolism, unsurprisingly it has also shown to have some extra-skeletal effects and in particular in numerous metabolic, degenerative, inflammatory and autoimmune rheumatic diseases. This is justified by at least four main aspects:

1) the presence of vitamin $D$ receptors in various tissues other than bone cells, such as cartilages, sinoviocytes and muscle cells;

2) the role of vitamin $D$ in the control of the transcription of genes involved in rheumatic diseases;

3) the evidence that vitamin D has multiple endocrine effects not only on calcium homeostasis;

4) the activation of vitamin D not only in the kidney, but also in monocyte-macrophage and lymphocytic cell lines and some epithelial cells.
The aim of this review is to summarize the latest evidence concerning the relationship between vitamin $\mathrm{D}$ and the most relevant rheumatic diseases, besides skeletal metabolic diseases.

\section{VITAMIN D AND OSTEOPOROSIS}

It has long been known that vitamin D plays an important role in the regulation of phosphorus, calcium and skeletal metabolism. Hence vitamin D deficiency may cause rickets in children and osteomalacia in adults and can contribute to the pathogenesis of osteoporosis. Over the last year new evidence has emerged of the relationship between vitamin $\mathrm{D}$ deficiency and the risk of osteoporosis and fractures (1-4). This is of particular interest, since fractures place a huge burden on healthcare services (5). A recent meta-analysis has demonstrated that patients with the bb-genotype of vitamin D receptor gene BsmI polymorphism
Corresponding author: Maurizio Rossini Rheumatology Unit University of Verona, Italy E-mail: maurizio.rossini@univr.it 
have statistically-significant slightly lower frequency of fracture (6). Furthermore in the past some studies demonstrated a strong correlation between bone mineral density (BMD) and some polymorphisms of this gene (7-9).

It has long been known that both calcium uptake and the level of vitamin D affect BMD. A recent study has shown that the former is more important than the latter, because a low calcium intake has detrimental effects only in patients with vitamin D deficiency (10). BMD loss is affected by the level of vitamin $D$, as confirmed by a recent prospective study in elderly male patients. In particular, in the group of over $75 \mathrm{~s}$, low levels of $25(\mathrm{OH}) \mathrm{D}(<20 \mathrm{ng} / \mathrm{mL})$ have shown to correlate with a faster BMD loss (11).

Vitamin D also correlates with other bone features, besides BMD. A positive correlation has been reported between $25 \mathrm{OH}$ vitamin $\mathrm{D}$ and some indices of bone quality, such as cortical thickness and axial and polar strength strain indices (12). Vitamin $\mathrm{D}$ deficiency also increases both the induction and the propagation of micro-cracks in the bone tissue (13).

Recent studies have highlighted the effects of vitamin D supplementation on BMD and other determinants of bone resistance and fractures. A Finnish study in women aged between 65 and 71 has shown that supplementation with 800 UI of vitamin D plus $1 \mathrm{~g}$ of calcium was associated with a significant increase in total body and femur BMD. This improvement was reasonably more significant in patients with a good level of compliance (14).

Unsurprisingly vitamin D supplementation proves useful only in patients with hypovitaminosis $\mathrm{D}$, as demonstrated by a recent Cochrane meta-analysis which has reported an increase in BMD after vitamin D supplementation only in young patients with low vitamin D levels (15). Recent studies have also demonstrated that vitamin D and calcium supplementation have some limited effects on some geometrical features of the bones, other than BMD, that correlate with bone resistance. In particular a structural analysis of the femur in a sub- group of female patients investigated in the Women's Health initiative trial has shown that calcium plus vitamin D supplementation preserves BMD better than placebo and can increase the cross-sectional area and the section modulus of the femur neck, which are geometrical properties inversely correlated with the risk of hip fracture (16). However the most important aspect of vitamin D supplementation is its capacity of reducing the risk of fracture. A recent meta-analysis has demonstrated a significant reduction of hip (-30\%) and non-vertebral fractures $(-14 \%)$ in patients treated with vitamin D (800 UI/die or more) (17). This supplementation strategy led to vitamin D serum levels higher than $20-24 \mathrm{ng} / \mathrm{mL}$ (i.e. 50-60 nmol/L).

However the administration of a daily dose of vitamin $\mathrm{D}$ can pose problems in terms of compliance, which on the contrary is an essential pre-requisite for its efficacy. It is likely that the same effects can be achieved with weekly or monthly doses, which may lead to the same serum levels of 25 OHD, provided adequate equivalent doses are administered $(18,19)$. In some cases a supplementation with a vitamin D bolus may also be justified, even though recent studies have unexpectedly reported an increased incidence of falls and fractures in women over 70 years treated with a 500,000 UI vitamin D bolus (20). This increase appeared to be more marked in the first 3 months after the bolus supplementation. However the population enrolled in this study included subjects with normal serum vitamin D levels, therefore such results may not be applicable to the Italian elderly population that is well-known to be affected by widespread hypovitaminosis D. A possible explanation for this unexpected increase in the incidence of falls may be paradoxically found in the potential extra-skeletal benefits of vitamin D, since they may allow elderly patients to have a more active life and consequently become more prone to falls. Another possible explanation may lie in the increase in bone turnover after non physiological peaks of serum levels of $25 \mathrm{OHD}$ and $1-25(\mathrm{OH} 2) \mathrm{D}$, as was observed after a supplementation of boluses of 300,000 
UI or more $(21,22)$. There is also further evidence of negative effects of vitamin D boluses in fracture prevention strategies, which however show significant limits and uncertain interpretations. For example an unexpected increase in hip fracture risk was reported after intramuscular administration of an annual bolus of 300,000 UI of vitamin D (23). However this result is questionable, since the subjects enrolled in the study had no vitamin D deficiency (the median 25OHD serum level was 56 $\mathrm{ng} / \mathrm{mL}$ at baseline). Also, as expected, the intramuscular administration, in particular of vitamin D2, could neither increase significantly serum levels of $25 \mathrm{OHD}$, nor decrease PTH levels. Also an oral supplementation of 100,000 UI of vitamin D2 every 4 months did not prove to correlate with a significant reduction in the incidence of fractures, probably because it involved low doses administered also in this case to subjects with no deficient serum levels (median serum 25OHD concentration of $54 \mathrm{nmol} / \mathrm{L}$ in the control group) (24). On the contrary, the administration of the same dose of vitamin D3 every 4 months has reduced the incidence of non-vertebral fractures (25). We have also reported a significant reduction in hip fractures after the administration of a single dose of 400,000 UI of vitamin D2 to elderly patients with a severe vitamin D deficiency $(<30 \mathrm{nmol} / \mathrm{L})$ in winter (26).

In any case the supplementation of high doses of vitamin D appears to be appropriate and is also recommended by the guidelines of the Italian Society of Osteoporosis, Mineral Metabolism and Skeletal Diseases (Società Italiana dell'Osteoporosi, del Metabolismo Minerale e delle Malattie dello Scheletro, SIOMMMS) for the treatment of vitamin D deficiency, provided adequate maintenance doses are administered subsequently on a daily, weekly or monthly basis $(27,28)$.

Furthermore the results of a previous study (29) were confirmed by a recent study, which has reported that an inadequate supplementation in patients with vitamin D deficiency is a risk factor for fractures during oral bisphophonate therapy (30).

\section{VITAMIN D AND MYOPATHIES}

As regards the possible effects of vitamin D on muscles, it should be noted that vitamin D receptors (VDR) are known to be present on muscle cells and their expression tends to decrease with aging (31). There is also recent evidence of non-receptor-mediated effects of vitamin D on muscle cells (32). Myocites contain mRNA for 25OHD-1-alpha-hydroxylase, which suggests a local independent conversion of 25OHD into 1-25OHD (33). It has also long been known that vitamin D stimulates the production of muscle proteins and can activate calcium transport in the sarcoplasmic reticulum, which is essential for muscular contraction. Patients with vitamin D deficiency have often shown signs of myopathies of the proximal muscles of the limbs (i.e. difficulty in standing up from a chair, functional deficit in raising arms over their head), sarcopenia and reduction of muscular strength with associated balance disorders that cause an increase in the risk of falls and fractures, especially in elderly patients.

A correlation between hypovitaminosis D and the risk of frailty syndromes (sarcopenia, weakness, exhaustion, slowness, low physical activity levels) has been recently observed (34), even though a similar correlation has also been unexpectedly observed with high vitamin D serum levels, which however is a very rare finding in elderly patients. It has also been observed that the level of vitamin D influences functional recovery following hip fractures (35). Patients with 25OHD levels higher than 25 $\mathrm{nmol} / \mathrm{L}$ (or $9 \mathrm{ng} / \mathrm{mL}$ ) reported a better physical performance and were at lower risk of falling. Also mortality after hip fracture was lower in patients treated with vitamin D after hip fracture (36).

An association between hypovitaminosis $\mathrm{D}$ and a subsequent decline in physical performance has been recently confirmed in particular in women (37). The timed upand-go test (i.e. the amount of time it takes to stand up from a chair, walk 3 meters, and return to the sitting position) and the timed chair standing test (i.e. the participants are seated on a straight-backed chair with their 
arms folded across their chests and are asked to stand up and sit down as quickly as possible for five times without stopping or using their arms) were significantly decreased after 2.5 years, in particular in women with vitamin D levels in the lowest quartile. In another study in 739 elderly women a positive correlation has been observed between 25OHD serum levels and fast walking speed (38). A recent study has shown that vitamin D deficiency significantly correlates with functional limitations and functional decline (39).

Furthermore an association has also been demonstrated between some genetic polymorphisms of VDR and the risk of falling. In particular this risk appears significantly greater in subjects carrying the $\mathrm{B}$ allele of Bsml polymorphism (40). This increased risk may be due to worst balance or muscular strength, which are present in patients carrying the $\mathrm{B}$ allele of Bsml polymorphism of VDR (41).

Is there any evidence that vitamin D supplementation can increase muscular strength? A recent randomized and controlled clinical trial has reported that a daily administration of 1000 UI of vitamin D to elderly women improves muscular function in the subset with the weakest and slowest patients (42). Two more studies have also recently reported an improvement in muscular performance after vitamin D administration $(43,44)$. A specific meta-analysis has demonstrated a trend close to statistical significance of the relationship between vitamin D supplementation and functional indices in the proximal muscles of lower limbs (45). As expected statistical significance has been largely obtained in subjects with a more severe deficiency, i.e. with $25 \mathrm{OHD}$ levels $<25 \mathrm{nmol} / \mathrm{L}$.

The role of hypovitamosis D-related myopathies in causing falls in elderly patients has been confirmed by the reduction in falls reported after the administration of adequate doses of vitamin D. Risk reduction close to the limit of statistical significance one year after the beginning of supplementation has been recently confirmed at 2 years (46) and has also been documented, especially if associated with calcium supplementation, in 3 recent meta-analyses (47-49). In particular a specific Cochrane meta-analysis has confirmed that vitamin D plus calcium supplementation leads to a $29 \%$ reduction in the incidence of falls, as compared with calcium supplementation alone (47). The lack of statistical significance associated with vitamin $\mathrm{D}$ supplementation alone may be due to the type of vitamin D used (D2 instead of D3) and to an insufficient dose (100,000 UI/3 months). It's actually wellknown that the longer the interval between the doses, the higher the cumulative dose must be as compared with the daily dose (19). Therefore a dose of 100,000 UI/3 months does not correspond to 1100 UI/ day, as stated by the authors. In another meta-analysis (50) it was observed that doses of at least $800 \mathrm{UI} /$ day (or equivalent weekly or monthly dosages) are needed to obtain a significant reduction of the risk of falling and to reach serum levels of $25 \mathrm{OHD}$ $>60 \mathrm{nmol} / \mathrm{L}$, which can be more easily obtained using vitamin D3, as is well-known. Also low 25OHD levels have been recently observed in patients affected by inflammatory idiopathic myopathies (51), even though in this group it is very easy to expect a causal relationship in which hypovitaminosis $\mathrm{D}$ is the consequence.

\section{VITAMIN D AND RHEUMATOID ARTHRITIS}

A correlation between the prevalence of rheumatoid arthritis (RA) and latitude has been described to confirm a potential association between hypovitaminosis $\mathrm{D}$ and the risk of RA (52). It has been observed that subjects with a higher vitamin $\mathrm{D}$ intake have a lower risk of developing RA (53), despite this finding has not been confirmed by subsequent studies $(54,55)$. The discrepancy between these studies may be attributable to a low accuracy in assessing vitamin D levels, which was estimated in both studies on the basis of food intake that is known to account only for $10-20 \%$ of endogenous vitamin $D$. Recently a negative correlation between ultraviolet-B (UV-B) light exposure and the risk of developing 
RA has actually been observed. However this may not be assessed in younger patients, because of a more widespread use of sun block creams (Fig. 1) (56).

Indirect evidence of a possible role of vitamin D in the etiopathogenesis of RA may derive from the correlation between genetic polymorphism of VDR and the risk of developing RA. It has been actually reported that the polymorphisms of FokI gene (allele B) for VDR are associated with an increased incidence of RA in both the Caucasian American population (OR 1.5, 95\% CI 1.16-1.95, $\mathrm{P}=0.002)(57)$ and the North American native population (58).

The most accurate approach to investigate any correlation between vitamin D and RA is to assess directly the level of $250 \mathrm{HD}$ in the serum. A study (59) reported an increased prevalence of vitamin D deficiency in patients affected by undifferentiated arthritis, which however was not confirmed by further evidence (60). Also no correlation has been found between levels of 25OHD and levels of rheumatoid factor and anti-cyclic citrullinated peptide antibodies (61).
We have recently conducted a multi-centric study on a wide Italian population that has demonstrated widespread vitamin D deficiency in patients affected by RA $(62,63)$. We have observed that most RA patients have low serum levels of 25OHD and also that current supplementation schemes with 400-800 UI/die of vitamin D is insufficient (Fig. 2) (62). This problem is also present in southern Italy, although in these regions sun exposure is greater due to more favorable latitude (64).

Some studies have also described an inverse correlation between disease activity and low levels of 25OHD $(62,65,66)$, although it has not been confirmed by other studies $(67,68)$. It is not actually clear if hypovitaminosis $\mathrm{D}$ in patients with active RA is simply a consequence of the associated disability, leading in particular to reduced sun exposure, or it directly contributes itself to inflammation and disability. We have observed a positive correlation between vitamin D levels and the probability of remission or good response to therapy and a negative correlation with disease activity and disability (Fig. 3) (62, 64). These

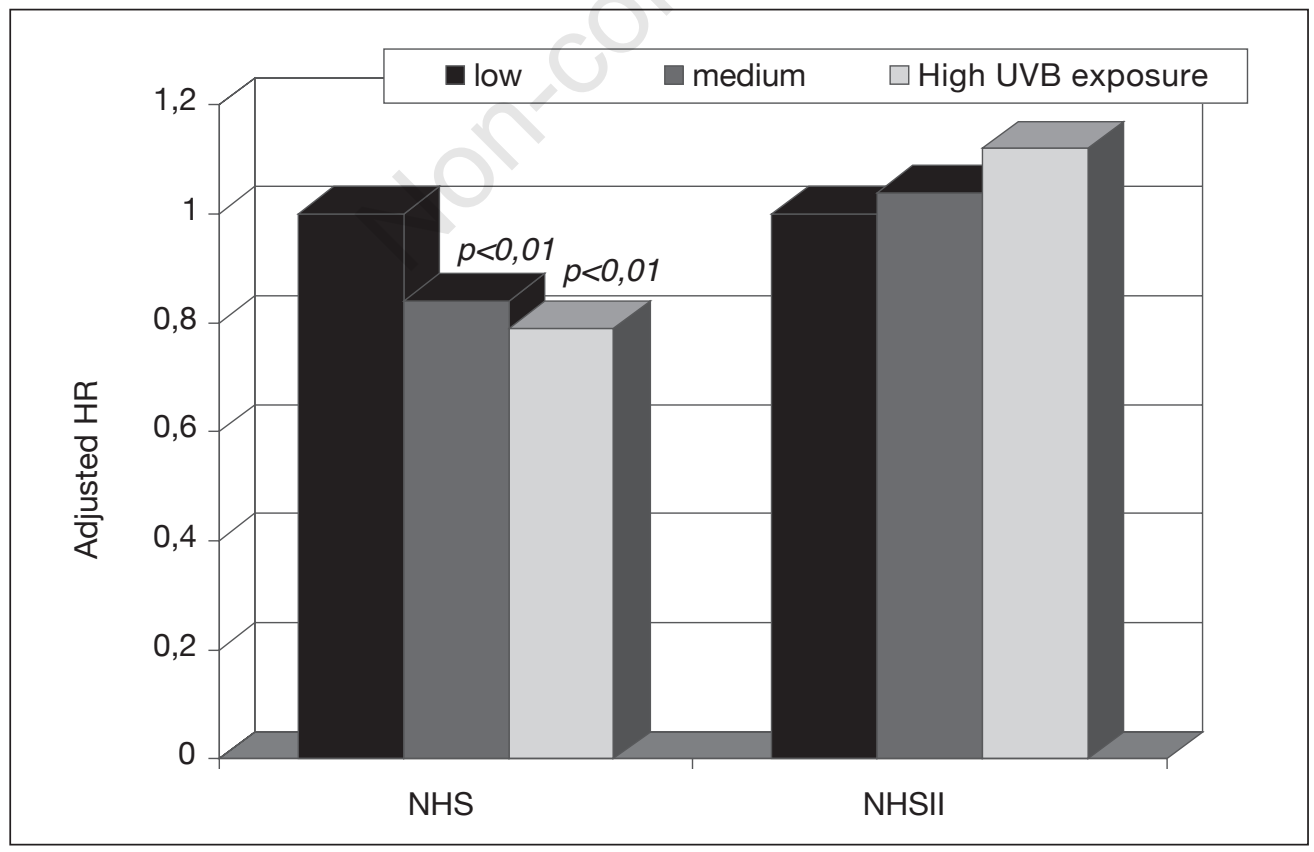

Figure 1 - UVB exposure and risk of developing rheumatoid arthritis in Nurses' Health Studies (NHS). Modified from: Arkema et al., 2013 (56). 


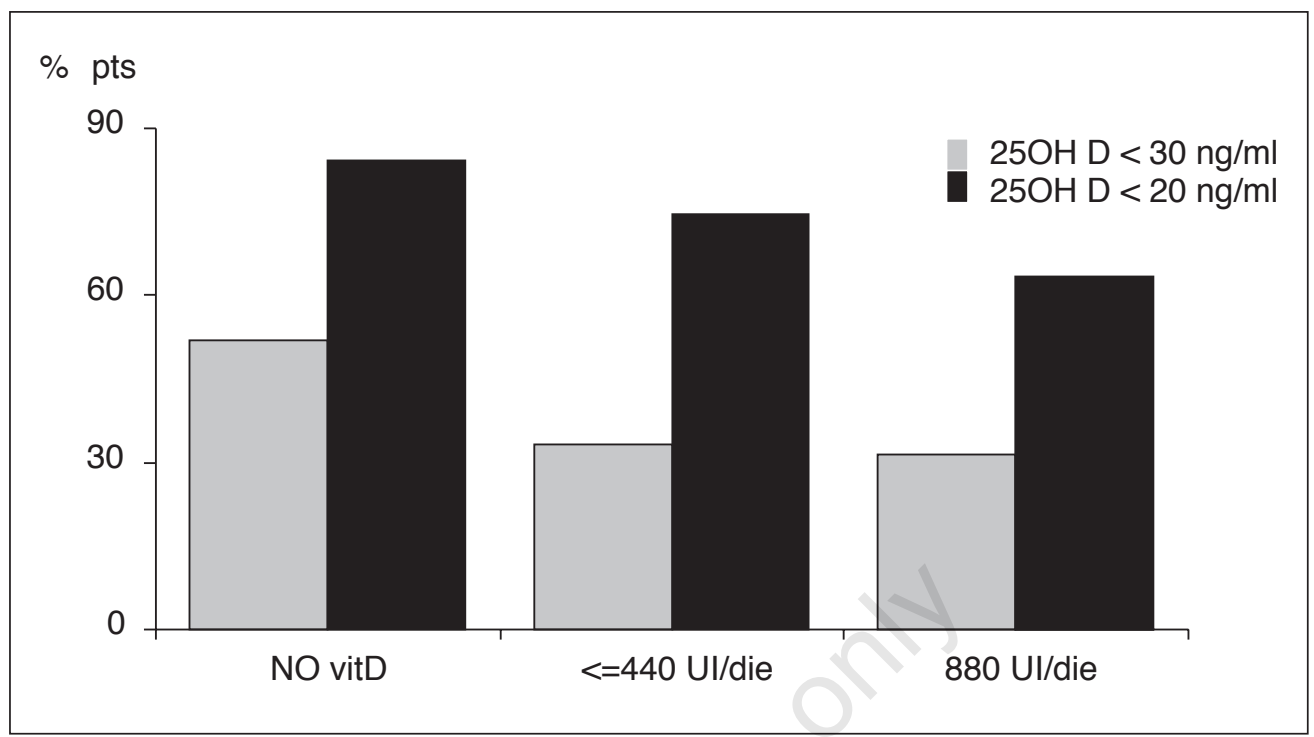

Figure 2 - Prevalence of vitamin D deficiency (25OHD serum levels $<20$ or $30 \mathrm{ng} / \mathrm{mL}$ ) in rheumatoid arthritis patients (pts) supplemented or not supplemented with vitamin D. Modified from: Rossini et al., 2010 (62).

results have also been confirmed after being adjusted for the main determinants of 25OHD serum levels (sun exposure, BMI and age). Therefore this may actually show that vitamin $\mathrm{D}$ has a role in controlling disease activity and in reducing the ensu- ing disability. As to a potential correlation between the typical bone complications of $\mathrm{RA}$, erosion and vitamin $\mathrm{D}$, we have also recently observed that a relevant independent risk factor is not so much the serum level of 25OHD, but an absolute or relative

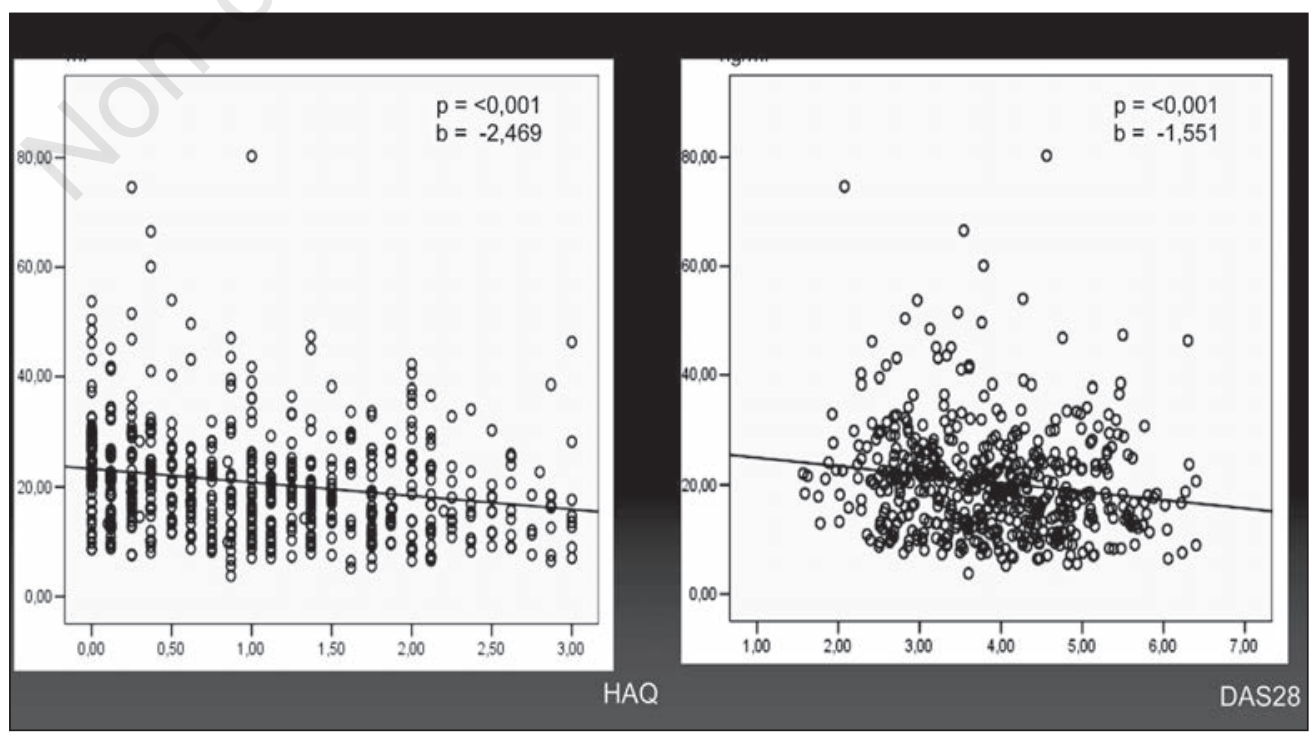

Figure 3 - Correlations between 25OHD serum levels, health assessment questionnaire disability index (HAQ) and disease activity score 28 (DAS28) in rheumatoid arthritis patients. Modified from: Rossini et al., 2013 (64). 
secondary hyperparathyroidism (69). This is also consistent with the recent observation of an increased progression of erosions, if the disease onset occurs in winter or in spring (70), which are marked by the lowest serum level of $25 \mathrm{OHD}$ and highest levels of parathyroid hormone.

Another potential bias in the studies on the correlation between 25OHD levels and the disease activity is the reported reduction of 25OHD levels during inflammation (71, 72). However it has also been observed that low levels of 25OHD do not increase with a reduction in the inflammation indicators and clinical remission after treatment with adalimumab (73) or rituximab (74).

Although in patients affected by RA vitamin D supplementation may have a rationale which goes beyond the mere prevention of osteoporosis (27), there are only a few trials that have actually demonstrated its benefits, also because of the ethical issues arising from the need to have a control group of subjects at risk of vitamin D deficiency to whom no supplementation should be administered.

Two studies have demonstrated a positive role of vitamin $\mathrm{D}$ in determining immunological modification that may have a favorable effect in patients affected by RA $(75,76)$.

A study conducted in India has documented that the association between disease-modifying antirheumatic drugs (DMARDs) and calcitriol plus calcium may have positive effects in patients with recent RA if compared with the association of DMARDs and calcium without calcitriol (77). Lastly an Israeli climatotherapy study has found a correlation between sun exposure and the ensuing increase in serum levels of $25 \mathrm{OHD}$, and the improvement of disease activity in patients with rheumatic diseases, including RA (78).

\section{VITAMIN D AND SYSTEMIC LUPUS ERYTHEMATOSUS}

Since sun exposure in patients with systemic lupus erythematosus (SLE) is a pos- sible risk factor for disease reactivation, it's not surprising that hypovitaminosis $\mathrm{D}$ is very common in these patients. Most studies are cross-sectional, therefore limited by the indefinable cause-effect relationship, have found lower levels of 25OHD in patients with SLE than in controls (79-86). It should also be noted that, unlike healthy individuals, SLE patients have abnormal serum levels of 25OHD also in summer (83).

It has been observed that on average 25OHD levels are lower in Afro-american women (known to have a high incidence of SLE) than in those living in Sierra Leone, where SLE incidence is low, thus supporting an etiopathogenetic role of hypovitaminosis D in SLE (87).

This may seem contrary to the lack of evidence of a correlation between food vitamin D intake and the risk of developing SLE $(54,55)$, but it's known that the dietary intake accounts only for a small portion of the vitamin D level. Furthermore the accuracy of these studies is poor since they have not taken into account sun exposure or serum levels of 25OHD.

The potential role of vitamin D deficiency in the etiopathogenesis and the clinical manifestation of SLE is corroborated by its correlations with VDR polymorphism (88). For example the Asian population has shown a correlation between the $\mathrm{B}$ allele of $B s m l$ polymorphism and the risk of developing SLE (OR 3.58, 95\% CI: 1.41-9.13, $\mathrm{P}=0.007$ ) (89). However this finding has not been confirmed in the Caucasian population $(90,91)$.

It has also been observed that low levels of vitamin $D$ are associated with an increased risk of anti-nuclear antibody (ANA) positivity, lymphocyte $\mathrm{B}$ activation and interferon- $\alpha$ activity (92). Other investigators have observed that the levels of anti-native DNA antibodies, anti-smith antibodies and immunoglobulin $\mathrm{G}$ increase as 25OHD decreases (93). Like in RA, also in SLE, there is evidence of a negative correlation between vitamin D levels and disease activity (93-99), also in pediatric patients (100-102).

A Canadian study has demonstrated that 
the total dose of steroids is associated with lower serum levels of $25 \mathrm{OHD}$ on average, thus suggesting a correlation between these levels and greater disease activity (99). In particular a negative correlation has been described between low vitamin $\mathrm{D}$ and a clinical indicator of SLE named SLE disease activity inventory (SLEDAI). As shown by an in vitro study, this correlation may be mediated by the effects of vitamin $\mathrm{D}$ on the differentiation and maturation of dendritic cells, which would become reversible by adding calcitriol (103). Additionally it has been observed that the reactivation of this disease can be triggered by significant seasonal drops in vitamin D levels (104).

Obviously such a correlation between vitamin $\mathrm{D}$ and disease activity may be explained also by a reduction of vitamin $\mathrm{D}$, which is a negative acute phase marker, caused by inflammation (71), but this hypothesis would not clarify the seasonal trend. Some studies have reported no correlation between serum levels of 25OHD and SLEDAI (105-106), but between vitamin D and fatigue (105), that is not considered a symptom in SLEDAI.

Therefore this index may not be the most appropriate indicator to assess disease activity. Clinical factors, such as post-menopausal status, pericarditis, neuropsychiatric disorders and deep vein thrombosis, have demonstrated to predict low levels of 25OHD in SLE (93).

Like in RA, also in SLE the strong rationale for supplementation with a low-cost product such as vitamin D has led for ethical and economic reasons to conduct only two observational studies $(105,107)$, which incidentally contradict each other, and one RCT of vitamin D supplementation in SLE, which has investigated a 50,000 UI weekly dose plus a 400 UI daily dose of vitamin D in patients with SLE and hypovitaminosis D $(25 \mathrm{OHD}<40 \mathrm{ng} / \mathrm{mL})(108)$. It has been observed that an increase of $20 \mathrm{ng} / \mathrm{mL}$ in 25OHD serum levels is associated with a $21 \%$ reduction in the risk of having a high disease activity index and a $15 \%$ reduction in the likelihood of having a clinically relevant proteinuria.

\section{VITAMIN D AND ANTI-PHOSPHOLIPID SYNDROME}

Also patients affected by anti-phospholipid syndrome have a higher prevalence of hypovitaminosis D than in healthy controls, except for springtime, when levels of 25OHD tend to be low in all groups (109). A very interesting finding is the correlation between hypovitaminosis D and risk of thrombosis, which may be attributable to the proven capacity of vitamin D of inhibiting the expression of the anti- $\beta 2 \mathrm{GPI}$ mediated tissue factor (110).

\section{VITAMIN D AND SYSTEMIC VASCULITIS}

It has been known that the antineutrophil cytoplasmatic antibody (ANCA)-associated vasculitis, in particular granulomatous polyangitis, have a higher prevalence in northern countries, that is thought to be attributable to low sun exposure and then low vitamin D synthesis (111).

\section{VITAMIN D AND SYSTEMIC SCLEROSIS}

Many studies have demonstrated a widespread hypovitaminosis $\mathrm{D}$ in patients affected by systemic sclerosis (112-117). Like in other diseases, low 25OHD levels may simply be caused by a limited sun exposure of these patients. The correlations between disease activity and its various clinical manifestations appear to be variable and occasionally absent, probably because of the heterogeneity of populations investigated (115-117). Furthermore the typical skin manifestations of this disease may reduce the synthesis of vitamin D and affect the other clinical manifestations in case the deficiency of this vitamin played a pathogenic role.

There is only one small double-blind RCT that has explored the effect of vitamin D supplementation on the disease activity and has found no significant differences 
between the systemic sclerosis group and placebo (118).

\section{VITAMIN D AND BEHÇET'S DISEASE}

Two studies $(119,120)$ have found a high prevalence of hypovitaminosis $\mathrm{D}$ in patients affected by Behçet's disease, which, according to one of them (120), is associated to a higher disease. The FokI $\mathrm{F}$ allele (F/F genotype) of a VDR gene has been demonstrated to be significantly associated with the risk of developing Bechet's disease, in particular with its typical vascular manifestations (121).

\section{VITAMIN D AND PSORIATIC ARTHRITIS}

Despite some exceptions attributable to better environmental conditions in terms of sun exposure (122), also patients with psoriatic arthritis (PsA) have shown on average low levels of vitamin D (123-125). Some studies have also identified a correlation with the disease activity (123). Furthermore it has been confirmed that, also in these patients, obesity $(123,125)$, a well-known risk factor for vitamin D deficiency, takes on a particular meaning both in terms of susceptibility to develop this disease and to show a weaker response to treatment (126). According to some small open-label studies, the treatment with 1,25-dihydroxyvitamin D3 or alphacalcidol would seem to have significant clinical and immunological effects in patients with PsA $(127,128)$.

\section{VITAMIN D AND SPONDYLOARTHRITIS}

Although no association between hypovitaminosis D and spondyloarthritis (SA) has been found, some studies have demonstrated a negative association between some disease activity indices and serum levels of 25OHD (129) and 1-25OHD (130). In addition no significant association has been found between the susceptibility to SA and vitamin $\mathrm{D}$ binding protein polymorphisms, but some haplotypes are associated with a higher risk of uveitis and a lower risk of peripheral arthritis (131). A proteomic study has found a correlation between a vitamin D metabolite and the disease activity, even though the cause-effect relationship is not yet well-understood (132).

\section{VITAMIN D AND FIBROMYALGIA}

Some studies (133-137) have observed an association, which is still poorly un-

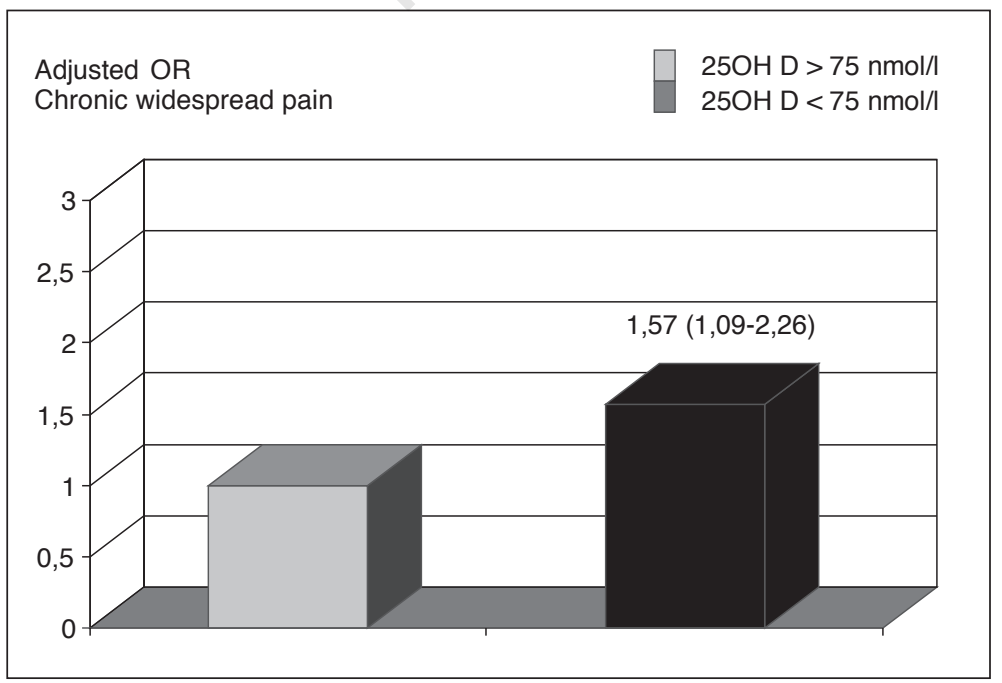

Figure 4 - Risk of chronic widespread pain in patients with vitamin $D$ deficiency. Modified from: Atherton et al., 2009 (133). 
derstood, between low vitamin D levels and the risk of fibromyalgia and chronic diffuse pain (Fig. 4) (133). Nevertheless the very limited number of studies which have investigated the effects of vitamin D supplementation on chronic diffused muscular-skeletal pain have not reported any convincing benefit $(138,139)$.

\section{VITAMIN D} AND OSTEOARTHRITIS

An additional problem in the assessment of vitamin D levels in case of osteoarthrosis is correlated with the variability of the diagnostic indicator considered. A large study conducted in Italy has found unexpectedly a correlation between low vitamin D levels and the risk of suffering from spondylosis-related low back pain, even after a multivariate adjustment (Fig. 5) (140).

The main studies on the potential role of polymorphisms of VDRs in patients affected by osteoarthritis have yielded conflicting results (141-145). Some studies have explored the correlation between vitamin D levels and the severity or progression of the disease. It has been observed that male patients with hypoitaminosis D have a double risk of having radiographic

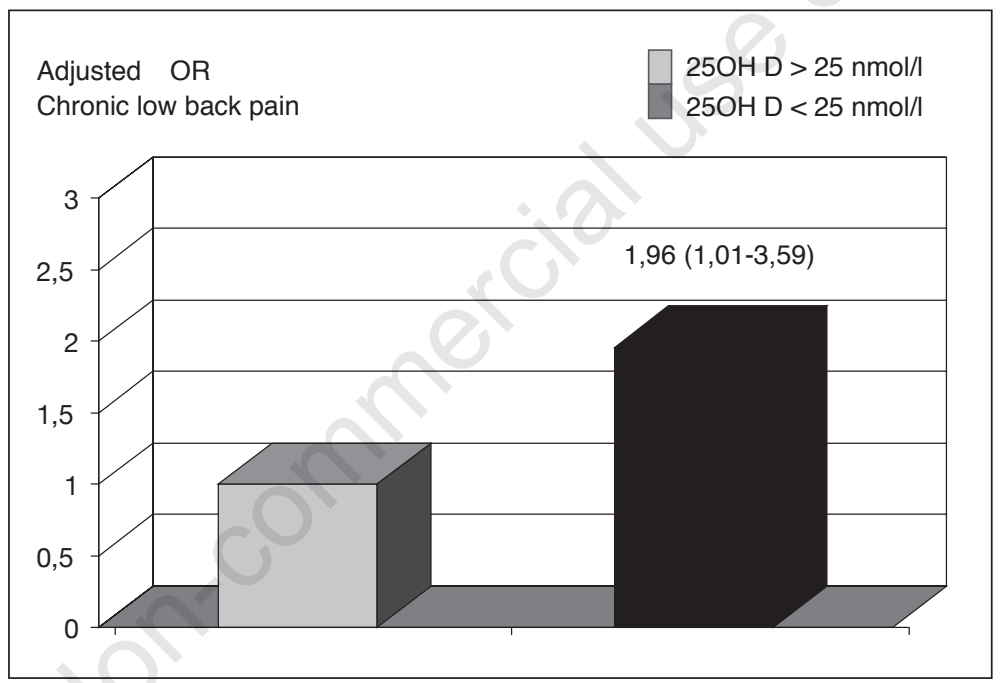

Figure 5 - Risk of chronic low back pain in patients with vitamin $\mathrm{D}$ deficiency. Modified from: Hicks et al., 2008 (140).

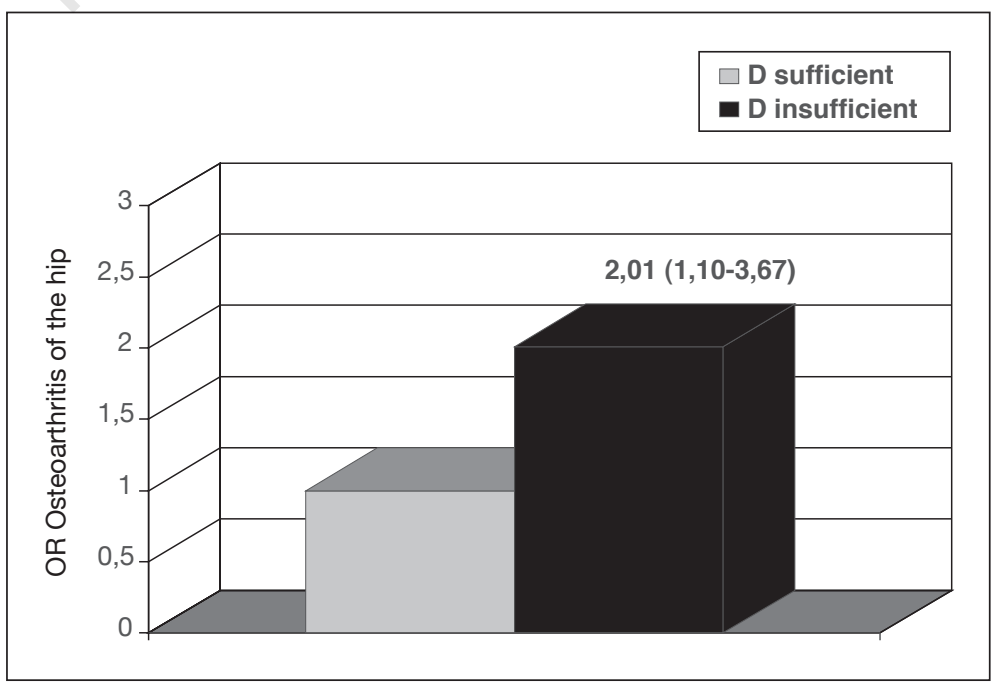

Figure 6 - Risk of hip osteoarthritis in patients with vitamin $\mathrm{D}$ deficiency. Modified from: Chaganti et al., 2010 (146). 
evidence of coxarthrosis (Fig. 6) (146). In an 8 years-prospective study it has been demonstrated that patients with hip osteoarthritis and low levels of 25OHD have an increased risk of joint space narrowing, but not of developing osteophytes (147). It has also been demonstrated that the knee cartilage volume, determined by nuclear magnetic resonance in female patients with knee osteoarthritis, is positively correlated with 25OHD levels, both at the baseline and prospectively (148).

Since vitamin D receptors are present on chondrocytes, hypovitaminosis D may reduce cartilage resistance to stress and therefore may play a role in the pathogenesis of osteoarthritis. In a prospective study conducted in Rotterdam, it has been observed that 25OHD levels were negatively associated with radiographic signs of osteoarthritis only in patients with low BMD (149). The risk of progression of osteoarthritis was eight-fold greater in patients in the lowest tertile of $250 \mathrm{HD}$ levels compared with patients in the highest tertile, despite a very wide interval of confidence (149).

On the contrary in the Framingham Osteoarthritis Study and in the Boston Osteoarthritis of the Knee Study, no significant correlation has been observed between basal vitamin D levels and further risk of joint space narrowing (150). In a study conducted in UK an increased risk of suffering from knee pain has been found in patients with serum levels of 25OHD in the lowest tertile (151).

Pain in patients with knee osteoarthritis seems actually to correlate with $25 \mathrm{OHD}$ levels (152). It has recently been reported that a moderate vitamin D deficiency can predicts the development or worsening of knee or hip pain after 2-5 years (153). However a recent RCT of vitamin D supplementation (2000 UI/die or more in order to reach serum levels of at least $36 \mathrm{ng} / \mathrm{mL}$ ) in patients with osteoarthritis has shown no improvement either in terms of symptoms or disease progression (154). Unfortunately this result is biased because most patients enrolled in this RCT had no vitamin D deficiency.

\section{BIBLIOGRAFIA}

1. Nakamura K, Saito T, Oyama M, Oshiki R, Kobayashi R, Nishiwaki T, et al. Vitamin D sufficiency is associated with low incidence of limb and vertebral fractures in community-dwelling elderly Japanese women: the Muramatsu Study. Osteoporos Int 2011; 22: 97-103.

2. de Koning L, Henne D, Hemmelgarn BR, Woods P, Naugler C. Non-linear relationship between serum 25-hydroxyvitamin D concentration and subsequent hip fracture. Osteoporos Int. 2013; 24: 2061-5.

3. Holvik K, Ahmed LA, Forsmo S, Gjesdal CG, Grimnes G, Samuelsen SO, et al. Low Serum Levels of 25-Hydroxyvitamin D Predict Hip Fracture in the Elderly: A NOREPOS Study. J Clin Endocrinol Metab. 2013; 98: 3341-50.

4. Looker AC. Serum 25-hydroxyvitamin D and risk of major osteoporotic fractures in older U.S. adults. J Bone Miner Res. 2013; 28: 997-1006.

5. Rossini M, Piscitelli P, Fitto F, Camboa P, Angeli A, Guida G, et al. Incidence and socioeconomic burden of hip fractures in Italy. Reumatismo. 2005; 57: 97-102.

6. Ji GR, Yao M, Sun CY, Li ZH, Han Z. BsmI, TaqI, ApaI and FokI polymorphisms in the vitamin D receptor (VDR) gene and risk of fracture in Caucasians: a meta-analysis. Bone. 2010; 47: 681-6.

7. Thakkinstian A, D'Este C, Eisman J, Nguyen T, Attia J. Meta-analysis of molecular association studies: vitamin $\mathrm{D}$ receptor gene polymorphisms and BMD as a case study. $\mathrm{J}$ Bone Miner Res. 2004; 19: 419-28.

8. Cooper GS, Umbach DM. Are vitamin D receptor polymorphisms associated with bone mineral density? A meta-analysis. J Bone Miner Res. 1996; 11: 1841-9.

9. Gong G, Stern HS, Cheng SC, Fong N, Mordeson J, Deng HW, et al. The association of bone mineral density with vitamin D receptor gene polymorphisms. Osteoporos Int. 1999; 9: 55-64.

10. Bischoff-Ferrari HA, Kiel DP, DawsonHughes B, Orav JE, Li R, Spiegelman D, et al. Dietary calcium and serum 25-hydroxyvitamin D status in relation to BMD among U.S. adults. J Bone Miner Res. 2009; 24: 935-42.

11. Ensrud KE, Taylor BC, Paudel ML, Cauley JA, Cawthon PM, Cummings SR, et al. Serum 25-hydroxyvitamin D levels and rate of hip bone loss in older men. J Clin Endocrinol Metab. 2009; 94: 2773-80.

12. Barbour KE, Zmuda JM, Horwitz MJ, Strotmeyer ES, Boudreau R, Evans RW, et al. The association of serum 25-hydroxyvitamin $\mathrm{D}$ with indicators of bone quality in 
men of Caucasian and African ancestry. Osteoporos Int. 2011; 22: 2475-85.

13. Busse B, Bale HA, Zimmermann EA, Panganiban B, Barth HD, Carriero A, et al. Vitamin d deficiency induces early signs of aging in human bone, increasing the risk of fracture. Sci Transl Med. 2013; 5: 193 ra88.

14. Karkkainen M, Tuppurainen M, Salovaara K, Sandini L, Rikkonen T, Sirola J, et al. Effect of calcium and vitamin D supplementation on bone mineral density in women aged 65-71 years: a 3-year randomized population-based trial (OSTPRE-FPS). Osteoporos Int. 2010; 21: 2047-55.

15. Winzenberg TM, Powell S, Shaw KA, Jones G. Vitamin D supplementation for improving bone mineral density in children. Cochrane Database Syst Rev. 2010; (10): CD006944.

16. Jackson RD, Wright NC, Beck TJ, Sherrill D, Cauley JA, Lewis CE, et al. Calcium plus vitamin D supplementation has limited effects on femoral geometric strength in older postmenopausal women: the Women's Health Initiative. Calcif Tissue Int. 2011; 88: 198-208.

17. Bischoff-Ferrari HA, Willett WC, Orav EJ, Lips P, Meunier PJ, Lyons RA, et al. A pooled analysis of vitamin $\mathrm{D}$ dose requirements for fracture prevention. N Engl J Med. 2012; 367: 40-9.

18. Rossini M, Viapiana O, Gatti D, James G, Girardello S, Adami S. The long term correction of vitamin D deficiency: comparison between different treatments with vitamin D in clinical practice. Minerva Med. 2005; 96: 1-7.

19. Chel V, Wijnhoven HA, Smit JH, Ooms M, Lips P. Efficacy of different doses and time intervals of oral vitamin D supplementation with or without calcium in elderly nursing home residents. Osteoporos Int. 2008; 19: 663-71.

20. Sanders KM, Stuart AL, Williamson EJ, Simpson JA, Kotowicz MA, Young D, et al. Annual high-dose oral vitamin D and falls and fractures in older women. JAMA. 2010; 303: $1815-22$.

21. Rossini M, Gatti D, Viapiana O, Fracassi E, Idolazzi L, Zanoni S, et al. Short-term effects on bone turnover markers of a single high dose of oral vitamin D. J Clin Endocrinol Metab. 2012; 97: E622-6.

22. Rossini M, Adami S, Viapiana O, Fracassi E, Idolazzi L, Povino MR, Gatti D. Dosedependent short-term effects of single high doses of oral vitamin $\mathrm{D}(3)$ on bone turnover markers. Calcif Tissue Int. 2012; 91: 365-9.

23. Smith H, Anderson F, Raphael H, Maslin P, Crozier S, Cooper C. Effect of annual intramuscular vitamin D on fracture risk in elderly men and women: a population- based, randomized, double-blind, placebocontrolled trial. Rheumatology. 2007; 46: 1852-7.

24. Lyons RA, Johansen A, Brophy S, Newcombe RG, Phillips CJ, Lervy B, et al. Preventing fractures among older people living in institutional care: a pragmatic randomised double blind placebo controlled trial of vitamin D supplementation. Osteoporos Int. 2007; 18: 811-8.

25. Trivedi DP, Doll R, Khau KT. Effect of four monthly vitamin D3 (cholecalciferol) supplementation on fractures and mortality in men and women living in the community: randomised double blind controlled trial. BMJ. 2003; 326: 469-72.

26. Rossini M, Alberti V, Flor L, Masiero L, Giannini S, Gatti D, et al. Effect of oral vitamin D2 yearly bolus on hip fracture risk in elderly women: a community primary prevention study. Aging Clin Exp Res. 2004; 16: 432-6.

27. Adami S, Bertoldo F, Brandi ML, Cepollaro C, Filipponi P, Fiore E, et al. Guidelines for the diagnosis, prevention and treatment of osteoporosis. Reumatismo. 2009; 61: 26084.

28. Adami S, Romagnoli E, Carnevale V, Scillitani A, Giusti A, Rossini M, et al. Guidelines on prevention and treatment of vitamin D deficiency. Reumatismo. 2011; 63: 129-47.

29. Adami S, Giannini S, Bianchi G, Sinigaglia L, Di Munno O, Fiore CE, et al. Vitamin D status and response to treatment in postmenopausal osteoporosis. Osteoporos Int. 2009; 20: 239-44.

30. Prieto-Alhambra D, Pagès-Castellà A, Wallace G, Javaid M, Judge A, Nogués X, et al. Predictors of fracture while on treatment with oral bisphosphonates: A populationbased cohort study. J Bone Miner Res. 2014; 29: 268-74.

31. Bischoff-Ferrari HA, Borchers M, Gudat F, Durmuller U, Stahelin HB, Dick W. Vitamin $\mathrm{D}$ receptor expression in human muscle tissue decreases with age. J Bone Miner Res. 2004; 19: 265-69.

32. Wang Y, DeLuca HF. Is the vitamin D receptor found in muscle? Endocrinology. 2011; 152: 354-63.

33. Srikuea R, Zhang X, Park-Sarge OK, Esser KA. VDR and CYP27B1 are expressed in $\mathrm{C} 2 \mathrm{C} 12$ cells and regenerating skeletal muscle: potential role in suppression of myoblast proliferation. Am J Physiol Cell Physiol. 2012; 303: C396-405.

34. Ensrud KE, Ewing SK, Fredman L, Hochberg C, Cauley JA, Hillier TA, et al. Circulating 25-hydroxyvitamin D levels and frailty status in older women. J Clin Endocrinol Metab. 2010; 95: 5266-73. 
35. LeBoff MS, Hawkes WG, Glowacki J, YuYahiro J, Hurwitz S, Magaziner J. Vitamin D-deficiency and post-fracture changes in lower extremity function and falls in women with hip fractures. Osteoporos Int. 2008; 19: 1283-90.

36. Nurmi-Lüthje I, Sund R, Juntunen M, Lüthje P. Post-hip fracture use of prescribed calcium plus vitamin D or vitamin D supplements and anti-osteoporotic drugs are associated with lower mortality. A nationwide study in Finland. J Bone Miner Res. 2011; 26: 1845-53.

37. Dam T-TL, von Muhlen D, Barrett-Connor EL. Sex-specific association of serum vitamin D levels with physical function in older adults. Osteoporos Int. 2009; 20: 751-60.

38. Annweiler C, Schott AM, Montero-Odasso M, Berrut G, Fantino B, Herrmann FR, et al. Cross-sectional association between serum vitamin D concentration and walking speed measured at usual and fast pace among older women: the EPIDOS study. J Bone Miner Res. 2010; 25: 1858-66.

39. Sohl E, van Schoor NM, de Jongh RT, Visser M, Deeg DJ, Lips P. vitamin D status is associated with functional limitations and functional decline in older individuals. J Clin Endocrinol Metab. 2013; 98: E148390.

40. Onder G, Capoluongo E, Danese P, Settanni S, Russo A, Concolino P, et al. Vitamin D receptor polymorphisms and falls among older adults living in the community: results from the ilSIRENTE study. J Bone Miner Res. 2008; 23: 1031-6.

41. Barr R, Macdonald H, Stewart A, McGuigan F, Rogers A, Eastell R, et al. Association between vitamin $\mathrm{D}$ receptor gene polymorphisms, falls, balance and muscle power: results from two independent studies (APOSS and OPUS). Osteoporos Int. 2010; 21: 457-66.

42. Zhu K, Austin N, Devine A, Bruce D, Prince RL. A randomized controlled trial of the effects of vitamin D on muscle strength and mobility in older women with vitamin D insufficiency. J Am Geriatr Soc. 2010; 58: 2063-8.

43. Gupta R, Sharma U, Gupta N, Kalaivani M, Singh U, Guleria R, et al. Effect of cholecalciferol and calcium supplementation on muscle strength and energy metabolism in vitamin D deficient Asian Indians: a randomized controlled trial. Clin Endocrinol. 2010; 73: 445-51.

44. Lagari V, Gómez-Marín O, Levis S. The role of vitamin $\mathrm{D}$ in improving physical performance in the elderly. J Bone Miner Res. 2013. (Epub ahead of print).

45. Stockton KA, Mengersen K, Paratz JD, Kandiah D, Bennell KL. Effect of vitamin
D supplementation on muscle strength: a systematic review and meta-analysis. Osteoporos Int. 2011; 22: 859-71.

46. Pfeifer M, Begerow B, Minne HW, Suppan K, Fahrleitner-Pammer A, Dobnig H. Effects of a long-term vitamin D and calcium supplementation on falls and parameters of muscle function in community-dwelling older individuals. Osteoporos Int. 2009; 20: 315-22.

47. Cameron ID, Murray GR, Gillespie LD, Robertson MC, Hill KD, Cumming RG, et al. Interventions for preventing falls in older people in nursing care facilities and hospitals. Cochrane Database Syst Rev 2010; (1): CD005465.

48. Kalyani RR, Stein B, Valiyil R, Manno R, Maynard JW, Crews DC. Vitamin D treatment for the prevention of falls in older adults: systematic review and meta-analysis. JAGS. 2010; 58: 1299-310.

49. Michael YL, Whitlock EP, Lin JS, Fu R, O'Connor EA, Gold R. Primary care-relevant interventions to prevent falling in older adults: a systematic evidence review for the U.S. Preventive Services Task Force. Ann Intern Med. 2010; 153: 815-25.

50. Bischoff-Ferrari HA, Dawson-Hughes B, Staehelin HB, Orav JE, Stuck AE, Theiler $\mathrm{R}$, et al. Fall prevention with supplemental and active forms of vitamin D: a meta-analysis of randomised controlled trials. BMJ. 2009; 339: b3692.

51. Azali P, Barbasso Helmers S, Kockum I, Olsson T, Alfredsson L, Charles PJ, et al. Low serum levels of vitamin D in idiopathic inflammatory myopathies. Ann Rheum Dis. 2013; 72: 512-6.

52. Ramos-Remus C, Sierra-Jimenez G, Skeith K, Aceves-Avila FJ, Russell AS, Offer R, et al. Latitude gradient influences the age of onset in rheumatoid arthritis patients. Clin Rheumatol. 2007; 26: 1725-8.

53. Merlino LA, Curtis J, Mikuls TR, Cerhan JR, Criswell LA, Saag KG, et al. Vitamin D intake is inversely associated with rheumatoid arthritis: results from the Iowa Women's Health Study. Arthritis Rheum. 2004; 50: 72-7.

54. Costenbader KH, Feskanich D, Holmes M, Karlson EW, Benito-Garcia E. Vitamin D intake and risks of systemic lupus erythematosus and rheumatoid arthritis in women. Ann Rheum Dis. 2008; 67: 530-5.

55. Hiraki LT, Munger KL, Costenbader KH, Karlson EW. Dietary intake of vitamin D during adolescence and risk of adult-onset systemic lupus erythematosus and rheumatoid arthritis. Arthritis Care Res. 2012; 64: 1829-36.

56. Arkema EV, Hart JE, Bertrand KA, Laden F, Grodstein F, Rosner BA, et al. Exposure 
to ultraviolet-B and risk of developing rheumatoid arthritis among women in the Nurses' Health Study. Ann Rheum Dis. 2013; 72: 506-11.

57. Lee YH, Bae SC, Choi SJ, Ji JD, Song GG. Associations between vitamin $\mathrm{D}$ receptor polymorphisms and susceptibility to rheumatoid arthritis and systemic lupus erythematosus: a meta-analysis. Mol Biol Rep. 2011; 38: 3643-51.

58. Hitchon CA, Sun Y, Robinson DB, Peschken CA, Bernstein CN, Siminovitch KA, et al. Vitamin D receptor polymorphism rs2228570 (Fok1) is associated with rheumatoid arthritis in North American natives. J Rheumatol. 2012; 39: 1792-7.

59. Heidari B, Hajian-Tilaki K, Heidari P. The status of serum vitamin D in patients with rheumatoid arthritis and undifferentiated inflammatory arthritis compared with controls. Rheumatol Int. 2012; 32: 991-5.

60. Cooles FA, Pratt AG, Wilson G, Isaacs JD, $\mathrm{Ng}$ WF. Prevalence and diagnostic outcome relating to vitamin $\mathrm{D}$ deficiency in new patients presenting to an early arthritis clinic over 12 months. Clin Rheumatol. 2011; 30: 1137-8.

61. Feser M, Derber LA, Deane KD, Lezotte DC, Weisman MH, Buckner JH, et al. Plasma $25, \mathrm{OH}$ vitamin $\mathrm{D}$ concentrations are not associated with rheumatoid arthritis (RA)related autoantibodies in individuals at elevated risk for RA. J Rheumatol. 2009; 36: 943-6.

62. Rossini M, Maddali Bongi S, La Montagna G, Minisola G, Malavolta N, Bernini L, et al. Vitamin D deficiency in rheumatoid arthritis: prevalence, determinants and associations with disease activity and disability. Arthritis Res Ther. 2010; 12: R216.

63. Varenna M, Manara M, Cantatore FP, Del Puente A, Di Munno O, Malavolta N, et al. Determinants and effects of vitamin D supplementation on serum 25-hydroxy-vitamin D levels in patients with rheumatoid arthritis. Clin Exp Rheumatol. 2012; 30: 714-9.

64. Rossini M, D’Avola G, Muratore M, Malavolta N, Silveri F, Bianchi G, et al. Regional differences of vitamin D deficiency in rheumatoid arthritis patients in Italy. Reumatismo. 2013; 65: 113-20.

65. Cutolo M, Otsa K, Laas K, Yprus M, Lehtme $\mathrm{R}$, Secchi ME, et al. Circannual vitamin d serum levels and disease activity in rheumatoid arthritis: Northern versus Southern Europe. Clin Exp Rheumatol. 2006; 24: 702-4.

66. Kerr GS, Sabahi I, Richards JS, Caplan L, Cannon GW, Reimold A, et al. Prevalence of vitamin $\mathrm{D}$ insufficiency/deficiency in rheumatoid arthritis and associations with disease severity and activity. J Rheumatol. 2011; 38: 53-9.
67. Craig SM, Yu F, Curtis JR, Alarcón GS, Conn DL, Jonas B, et al. Vitamin D status and its associations with disease activity and severity in African Americans with recent-onset rheumatoid arthritis. J Rheumatol. 2010; 37: 275-81.

68. Baker JF, Baker DG, Toedter G, Shults J, Von Feldt JM, Leonard MB. Associations between vitamin $\mathrm{D}$, disease activity, and clinical response to therapy in rheumatoid arthritis. Clin Exp Rheumatol. 2012; 30: 658-64.

69. Rossini M, Bagnato G, Frediani B, Iagnocco A, La Montagna G, Minisola G, et al. Relationship of focal erosions, bone mineral density, and parathyroid hormone in rheumatoid arthritis. J Rheumatol. 2011; 38: 997-1002.

70. Mouterde G, Lukas C, Logeart I, Flipo RM, Rincheval N, Daurès JP, et al. Predictors of radiographic progression in the ESPOIR cohort: the season of first symptoms may influence the short-term outcome in early arthritis. Ann Rheum Dis. 2011; 70: 12516.

71. Ried D, Toole BJ, Knox S, Talwar D, Harten J, O'Reilly DS, et al. The relation between acute changes in the systemic inflammatory response and plasma 25 -hydroxyvitamin D concentrations after elective knee arthroplasty. Am J Clin Nutr. 2011; 93: 1006-11.

72. Gama R, Waldron JL, Ashby HL, Cornes MP, Bechervaise J, Razavi C, et al. Hypovitaminosis D and disease: consequence rather than cause? BMJ. 2012; 345: e5706.

73. Welsh P, Peters MJ, McInnes IB, Lems WF, Lips PT, McKellar G, et al. Vitamin D deficiency is common in patients with RA and linked to disease activity, but circulating levels are unaffected by TNFalpha blockade: results from a prospective cohort study. Ann Rheum Dis. 2011; 70: 1165-7.

74. Hasan E, Olusi S, Al-Awadhi A, Mokaddem K, Sharma P, George S. Effects of rituximab treatment on the serum concentrations of vitamin D and interleukins 2, 6, 7, and 10 in patients with rheumatoid arthritis. Biologics. 2012; 6: 31-5.

75. Bansal AS, Henriquez F, Sumar N, Patel S. T helper cell subsets in arthritis and the benefits of immunomodulation by $1,25(\mathrm{OH})(2)$ vitamin D. Rheumatol Int. 2012; 32: 84552.

76. van Hamburg JP, Asmawidjaja PS, Davelaar N, Mus AM, Cornelissen F, van Leeuwen JP, et al. TNF blockade requires $1,25(\mathrm{OH}) 2 \mathrm{D} 3$ to control human Th17-mediated synovial inflammation. Ann Rheum Dis. 2012; 71: 606-12.

77. Gopinath K, Danda D. Supplementation of 1,25 dihydroxy vitamin D3 in patients with treatment naive early rheumatoid arthritis: 
a randomised controlled trial. Int $\mathrm{J}$ Rheum Dis. 2011; 14: 332-9.

78. Harari M, Dramsdahl E, Shany S, Baumfeld Y, Ingber A, Novack V, et al. Increased vitamin D serum levels correlate with clinical improvement of rheumatic diseases after Dead Sea climatotherapy. Isr Med Assoc J. 2011; 13: 212-5.

79. Bogaczewicz J, Sysa-Jedrzejowska A, Arkuszewska C, Zabek J, Kontny E, McCauliffe D, et al. Vitamin D status in systemic lupus erythematosus patients and its association with selected clinical and laboratory parameters. Lupus. 2012; 21: 477-84.

80. Cutillas-Marco E, Morales-Suarez-Varela M, Marquina-Vila A, Grant W. Serum 25-hydroxyvitamin D levels in patients with cutaneous lupus erythematosus in a Mediterranean region. Lupus. 2010; 19: 810-4.

81. Damanhouri LH. Vitamin D deficiency in Saudi patients with systemic lupus erythematosus. Saudi Med J. 2009; 30: 1291-5.

82. Hamza RT, Awwad KS, Ali MK, Hamed AI. Reduced serum concentrations of 25-hydroxy vitamin D in Egyptian patients with systemic lupus erythematosus: relation to disease activity. Med Sci Monit. 2011; 17: CR711-8.

83. Heine G, Lahl A, Muller C, Worm M. Vitamin $\mathrm{D}$ deficiency in patients with cutaneous lupus erythematosus is prevalent throughout the year. Br J Dermatol. 2010; 163: 8635.

84. Kim HA, Sung JM, Jeon JY, Yoon JM, Suh $\mathrm{CH}$. Vitamin D may not be a good marker of disease activity in Korean patients with systemic lupus erythematosus. Rheumatol Int. 2011; 31: 1189-94.

85. Muñoz-Ortego J, Torrente-Segarra V, Prieto-Alhambra D, Salman-Monte TC, Carbonell-Abello J. Prevalence and predictors of vitamin D deficiency in nonsupplemented women with systemic lupus erythematosus in the Mediterranean region: a cohort study. Scand J Rheumatol. 2012; 41: 472-5.

86. Souto M, Coelho A, Guo C, Mendonça L, Argolo S, Papi J, et al. Vitamin D insufficiency in Brazilian patients with SLE: prevalence, associated factors, and relationship with activity. Lupus. 2011; 20: 1019-26.

87. Gilkeson G, James J, Kamen D, Knackstedt T, Maggi D, Meyer A, et al. The United States to Africa lupus prevalence gradient revisited. Lupus. 2011; 20: 1095-103.

88. Lee YH, Bae SC, Choi SJ, Ji JD, Song GG. Associations between vitamin D receptor polymorphisms and susceptibility to rheumatoid arthritis and systemic lupus erythematosus: a meta-analysis. Mol Biol Rep. 2011; 38: 3643-51.

89. Luo XY, Yang MH, Wu FX, Wu LJ, Chen
L, Tang Z, et al. Vitamin D receptor gene BsmI polymorphism B allele, but not BB genotype, is associated with systemic lupus erythematosus in a Han Chinese population. Lupus. 2012; 21: 53-9.

90. Abbasi M, Rezaieyazdi Z, Afshari JT, Hatef M, Sahebari M, Saadati N. Lack of association of vitamin D receptor gene BsmI polymorphisms in patients with systemic lupus erythematosus. Rheumatol Int. 2010; 30: 1537-9.

91. Monticielo OA, Brenol JC, Chies JA, Longo MG, Rucatti GG, Scalco R, et al. The role of BsmI and FokI vitamin D receptor gene polymorphisms and serum 25-hydroxyvitamin D in Brazilian patients with systemic lupus erythematosus. Lupus. 2012; 21: 4352.

92. Ritterhouse LL, Crowe SR, Niewold TB, Kamen DL, Macwana SR, Roberts VC, et al. Vitamin D deficiency is associated with an increased autoimmune response in healthy individuals and in patients with systemic lupus erythematosus. Ann Rheum Dis. 2011; 70: 1569-74.

93. Szodoray P, Tarr T, Bazso A, Poor G, Szegedi G, Kiss E. The immunopathological role of vitamin D in patients with SLE: data from a single centre registry in Hungary. Scand J Rheumatol. 2011; 40: 122-6.

94. Mok CC, Birmingham DJ, Ho LY, Hebert LA, Song H, Rovin BH. Vitamin D deficiency as marker for disease activity and damage in systemic lupus erythematosus: a comparison with antidsDNA and anti-C1q. Lupus. 2012; 21: 36-42.

95. Mok CC, Birmingham DJ, Leung HW, Hebert LA, Song H, Rovin BH. Vitamin D levels in Chinese patients with systemic lupus erythematosus: relationship with disease activity, vascular risk factors and atherosclerosis. Rheumatology (Oxford). 2012; 51: 644-52.

96. Yeap SS, Othman AZ, Zain AA, Chan SP. Vitamin D levels: its relationship to bone mineral density response and disease activity in premenopausal Malaysian systemic lupus erythematosus patients on corticosteroids. Int J Rheum Dis. 2012; 15: 17-24.

97. Bonakdar ZS, Jahanshahifar L, Jahanshahifar F, Gholamrezaei A. Vitamin D deficiency and its association with disease activity in new cases of systemic lupus erythematosus. Lupus. 2011; 20: 1155-60.

98. Amital H, Szekanecz Z, Szücs G, Dankó K, Nagy E, Csépány T, et al. Serum concentrations of 25-OH vitamin D in patients with systemic lupus erythematosus (SLE) are inversely related to disease activity: is it time to routinely supplement patients with SLE with vitamin D? Ann Rheum Dis. 2010; 69: 1155-7. 
99. Toloza SM, Cole DE, Gladman DD, Ibañez D, Urowitz MB. Vitamin D insufficiency in a large female SLE cohort. Lupus. 2010; 19: 13-9.

100. Wright TB, Shults J, Leonard MB, Zemel BS, Burnham JM. Hypovitaminosis D is associated with greater body mass index and disease activity in pediatric systemic lupus erythematosus. J Pediatr. 2009; 155: 260-5.

101. Casella CB, Seguro LP, Takayama L, Medeiros D, Bonfa E, Pereira RM. Juvenile onset systemic lupus erythematosus: a possible role for vitamin $\mathrm{D}$ in disease status and bone health. Lupus. 2012; 21: 1335-42.

102. Robinson AB, Thierry-Palmer M, Gibson KL, Rabinovich CE. Disease activity, proteinuria, and vitamin D status in children with systemic lupus erythematosus and juvenile dermatomyositis. J Pediatr. 2012; 160: 297-302.

103. Ben-Zvi I, Aranow C, Mackay M, Stanevsky A, Kamen DL, Marinescu LM, et al. The impact of vitamin D on dendritic cell function in patients with systemic lupus erythematosus. PLoS One. 2010; 5: e9193.

104. Birmingham DJ, Hebert LA, Song H, Noonan WT, Rovin BH, Nagaraja HN, et al. Evidence that abnormally large seasonal declines in vitamin D status may trigger SLE flare in non-African Americans. Lupus. 2012; 21: 855-64.

105. Ruiz-Irastorza G, Gordo S, Olivares N, Egurbide MV, Aguirre C. Changes in vitamin D levels in patients with systemic lupus erythematosus: Effects on fatigue, disease activity, and damage. Arthritis Care Res (Hoboken). 2010; 62: 1160-5.

106. Kim HA, Sung JM, Jeon JY, Yoon JM, Suh $\mathrm{CH}$. Vitamin D may not be a good marker of disease activity in Korean patients with systemic lupus erythematosus. Rheumatol Int. 2011; 31: 1189-94.

107. Aghdassi E, Wendland BE, Stapleton M, Raman M, Allard JP. The use of micronutrient supplements is not associated with better quality of life and disease activity in Canadian patients with systemic lupus erythematosus. J Rheumatol. 2010; 37: 87-90.

108. Petri M, Bello KJ, Fang H, Magder LS. Vitamin D in systemic lupus erythematosus. Arthitis Rheum. 2013; 65: 1865-71.

109. Andreoli L, Piantoni S, Dall'Ara F, Allegri F, Meroni PL, Tincani A. Lupus Vitamin $\mathrm{D}$ and antiphospholipid syndrome. Lupus. 2012; 21: 736-40.

110. Agmon-Levin N, Blank M, Zandman-Goddard G, Orbach H, Meroni PL, Tincani A, et al. Vitamin D: an instrumental factor in the anti-phospholipid sindrome by inhibition of tissue factor expression. Ann Rheum Dis. 2011; 70: 145-50.

111. Gatenby PA, Lucas RM, Engelsen O, Pon- sonby AL, Clements M. Antineutrophil cytoplasmic antibody- associated vasculitides: could geographic patterns be explained by ambient ultraviolet radiation? Arthritis Rheum. 2009; 61: 1417-24.

112. Vacca A, Cormier C, Piras M, Mathieu A, Kahan A, Allanore Y. Vitamin D deficiency and insufficiency in 2 independent cohorts of patients with systemic sclerosis. J Rheumatol. 2009; 36: 1924-29.

113. Calzolari G, Data V, Carignola R, Angeli A. Hypovitaminosis D in systemic sclerosis. J Rheumatol. 2009; 36: 2844.

114. Caramaschi P, Dalla Gassa A, Ruzzenente O, Volpe A, Ravagnani V, Tinazzi I, et al. Very low levels of vitamin D in systemic sclerosis patients. Clin Rheumatol. 2010; 29: 1419-25.

115. Belloli L, Ughi N, Marasini B. Vitamin D in systemic sclerosis. Clin Rheumatol. 2011; 30: 145-6.

116. Arnson Y, Amital H, Agmon-Levin N, Alon D, Sánchez-Castañón M, López-Hoyos M, et al. Serum $25-\mathrm{OH}$ vitamin D concentrations are linked with various clinical aspects in patients with systemic sclerosis: a retrospective cohort study and review of the literature. Autoimmun Rev. 2011; 10: 490-4.

117. Gambichler T, Chrobok I, Hoxtermann S, Kreuter A. Significantly decreased serum 25-hydroxyvitamin d levels in a large german systemic sclerosis cohort. J Rheumatol. 2011; 38: 2492-3.

118. Hulshof MM, Bouwes Bavinck JN, Bergman W, Masclee AA, Heickendorff L, Breedveld FC, et al. Double-blind, placebocontrolled study of oral calcitriol for the treatment of localized and systemic scleroderma. J Am Acad Dermatol. 2000; 43: 1017-23.

119. Hamzaoui K, Ben Dhifallah I, Karray E, Sassi FH, Hamzaoui A. Vitamin D modulates peripheral immunity in patients with Behcet's disease. Clin Exp Rheumatol. 2010; 28: S50-7.

120. Karatay S, Yildirim K, Karakuzu A, Kiziltunc A, Engin RI, Eren YB, et al. Vitamin D status in patients with Behcet's Disease. Clinics (Sao Paulo). 2011; 66: 721-3.

121. Karray EF, Ben Dhifallah I, Ben Abdelghani K, Ben Ghorbel I, Khanfir M, Houman $\mathrm{H}$, et al. Associations of vitamin D receptor gene polymorphisms FokI and BsmI with susceptibility to rheumatoid arthritis and Behcet's disease in Tunisians. Joint Bone Spine. 2012; 79: 144-8.

122. Braun-Moscovici Y, Toledano K, Markovits D, Rozin A, Nahir AM, Balbir-Gurman A. Vitamin D level: is it related to disease activity in inflammatory joint disease? Rheumatol Int. 2011; 31: 493-9.

123. Orgaz-Molina J, Buendia-Eisman A, Ar- 
rabal-Polo MA, Ruiz JC, Arias-Santiago S. Deficiency of serum concentration of 25-hydroxyvitamin D in psoriatic patients: a case-control study. J Am Acad Dermatol. 2012; 67: 931-8.

124. Touma Z, Eder L, Zisman D, Feld J, Chandran V, Rosen CF, et al. Seasonal variation in vitamin D levels in psoriatic arthritis patients from different latitudes and its association with clinical outcomes. Arthritis Care Res (Hoboken). 2011; 63: 1440-7.

125. Gisondi P, Rossini M, Di Cesare A, Idolazzi L, Farina S, Beltrami G, et al. Vitamin D status in patients with chronic plaque psoriasis. Br J Dermatol. 2012; 166: 505-10.

126. Di Minno MN, Peluso R, Iervolino S, Russolillo A, Lupoli R, Scarpa R, et al. Weight loss and achievement of minimal disease activity in patients with psoriatic arthritis starting treatment with tumour necrosis factor $\alpha$ blockers. Ann Rheum Dis. 2013. (Epub ahead of print).

127. Huckins D, Felson DT, Holick M. Treatment of psoriatic arthritis with oral 1,25-dihydroxyvitamin D3: a pilot study. Arthritis Rheum. 1990; 33: 1723-7.

128. Gaal J, Lakos G, Szodoray P, Kiss J, Horváth $\mathrm{I}$, Horkay $\mathrm{E}$, et al. Immunological and clinical effects of alphacalcidol in patients with psoriatic arthropathy: results of an open, follow up pilot study. Acta Derm Venereol. 2009; 89: 140-4.

129. Durmus B, Altay Z, Baysal O, Ersoy Y. Does vitamin $D$ affect disease severity in patients with ankylosing spondylitis? Chin Med J (Engl). 2012; 125: 2511-5.

130. Lange U, Jung O, Teichmann J, Neeck G. Relationship between disease activity and serum levels of vitamin D metabolites and parathyroid hormone in ankylosing spondylitis. Osteoporos Int. 2001; 12: 1031-5.

131. Jung KH, Kim TH, Sheen DH, Lim MK, Lee SK, Kim JY, et al. Associations of vitamin $\mathrm{D}$ binding protein gene polymorphisms with the development of peripheral arthritis and uveitis in ankylosing spondylitis. J Rheumatol. 2011; 38: 2224-9.

132. Fischer R, Trudgian DC, Wright C, Thomas G, Bradbury LA, Brown MA, et al. Discovery of candidate serum proteomic and metabolomic biomarkers in ankylosing spondylitis. Mol Cell Proteomics. 2012; 11: M111.013904.

133. Atherton K, Berry DJ, Parsons T, Macfarlane GJ, Power C, Hyppönen E. Vitamin $\mathrm{D}$ and chronic widespread pain in a white middle-aged British population: evidence from a cross-sectional population survey. Ann Rheum Dis. 2009; 68: 817-22.

134. Heidari B, Shirvani JS, Firouzjahi A, Heidari P, Hajian-Tilaki KO. Association between nonspecific skeletal pain and vita- min D deficiency. Int J Rheum Dis. 2010; 13: 340-6.

135. Bhatty SA, Shaikh NA, Irfan M, Kashif SM, Vaswani AS, Sumbhai A, et al. Vitamin $\mathrm{D}$ deficiency in fibromyalgia. J Pak Med Assoc. 2010; 60: 949-51.

136. Macfarlane GJ, Palmer B, Roy D, Afzal C, Silman AJ, O'Neill T. An excess of widespread pain among South Asians: are low levels of vitamin D implicated? Ann Rheum Dis. 2005; 64: 1217-9.

137. McBeth J, Pye SR, O’Neill TW, Macfarlane GJ, Tajar A, Bartfai G, et al. Musculoskeletal pain is associated with very low levels of vitamin D in men: results from the European Male Ageing Study. Ann Rheum Dis. 2010; 69: 1448-52.

138. Straube S, Derry S, Moore RA, McQuay HJ. Vitamin D for the treatment of chronic painful conditions in adults. Cochrane Database Syst Rev. 2010; (1): CD007771.

139. Warner AE, Arnspiger S. A. Diffuse musculoskeletal pain is not associated with low vitamin $\mathrm{D}$ levels or improved by treatment with vitamin D. J Clin Rheumatol. 2008; 14: $12-6$

140. Hicks GE, Shardell M, Miller RR, Bandinelli S, Guralnik J, Cherubini A, et al. Associations between vitamin $\mathrm{D}$ status and pain in older adults: the Invecchiare in Chianti study. J Am Geriatr Soc. 2008; 56: 785-91.

141. Uitterlinden AG, Burger H, Huang Q, Odding E, Duijn CM, Hofman A, et al. Vitamin $\mathrm{D}$ receptor genotype is associated with radiographic osteoarthritis at the knee. J Clin Invest. 1997; 100: 259-63.

142. Huang J, Ushiyama T, Inoue K, Kawasaki T, Hukuda S. Vitamin D receptor gene polymorphisms and osteoarthritis of the hand, hip, and knee: a case-control study in Japan. Rheumatology (Oxford). 2000; 39: 7984.

143. Videman T, Gibbons LE, Battié MC, Maravilla K, Vanninen E, Leppävuori J, et al. The relative roles of intragenic polymorphisms of the vitamin D receptor gene in lumbar spine degeneration and bone density. Spine (Phila Pa 1976). 2001; 26: E7-12.

144. Solovieva S, Hirvonen A, Siivola P, Vehmas $\mathrm{T}$, Luoma K, Riihimäki H, et al. Vitamin $\mathrm{D}$ receptor gene polymorphisms and susceptibility of hand osteoarthritis in Finnish women. Arthritis Res Ther. 2006; 8: R20.

145. arcOGEN Constorium, arcOGEN Collaborators, Zeggini E, Panoutsopoulou K, Southam L, Rayner NW, et al. Identification of new susceptibility loci for osteoarthritis (arcOGEN): a genome-wide association study. Lancet. 2012; 380: 815-23.

146. Chaganti RK, Parimi N, Cawthon P, Dam TL, Nevitt MC, Lane NE. Association of 25-hydroxyvitamin D with prevalent osteo- 
arthritis of the hip in elderly men: the osteoporotic fractures in men study. Arthritis Rheum. 2010; 62: 511-4.

147. Lane NE, Gore LR, Cummings SR, Hochberg MC, Scott JC, Williams EN, et al. Serum vitamin $\mathrm{D}$ levels and incident changes of radiographic hip osteoarthritis: a longitudinal study. Study of Osteoporotic Fractures Research Group. Arthritis Rheum. 1999; 42: 854-60.

148. Ding C, Cicuttini F, Parameswaran V, Burgess J, Quinn S, Jones G. Serum levels of vitamin $\mathrm{D}$, sunlight exposure, and knee cartilage loss in older adults: the Tasmanian older adult cohort study. Arthritis Rheum. 2009; 60: 1381-9.

149. Bergink AP, Uitterlinden AG, Van Leeuwen JP, Buurman CJ, Hofman A, Verhaar JA, et al. Vitamin D status, bone mineral density, and the development of radiographic osteoarthritis of the knee: the Rotterdam Study. J Clin Rheumatol. 2009; 15: 230-7.

150. Felson DT, Niu J, Clancy M, Aliabadi P, Sack B, Guermazi A, et al. Low levels of vitamin $\mathrm{D}$ and worsening of knee osteoar- thritis: results of two longitudinal studies. Arthritis Rheum. 2007; 56: 129-36.

151. Muraki S, Dennison E, Jameson K, Boucher BJ, Akune T, Yoshimura N, et al. Association of vitamin D status with knee pain and radiographic knee osteoarthritis. Osteoarthritis Cartilage. 2011; 19: 1301-6.

152. Glover TL, Goodin BR, Horgas AL, Kindler LL, King CD, Sibille KT, et al. Vitamin D, race, and experimental pain sensitivity in older adults with knee osteoarthritis. Arthritis Rheum. 2012; 64: 3926-35.

153. Laslett LL, Quinn S, Burgess JR, Parameswaran V, Winzenberg TM, Jones G, et al. Moderate vitamin D deficiency is associated with changes in knee and hip pain in older adults: a 5-year longitudinal study. Ann Rheum Dis. 2014; 73: 697-703.

154. McAlindon T, LaValley M, Schneider E, Nuite M, Lee JY, Price LL, et al. Effect of vitamin D supplementation on progression of knee pain and cartilage volume loss in patients with symptomatic osteoarthritis: a randomized controlled trial. JAMA. 2013; 309: 155-62. 